Original Research Article

\title{
Preclinical evaluation of antidepressant activity of aqueous extract of Piper betle leaves in Swiss albino mice
}

\author{
Uttara Krishna, Roopa P. Nayak*, Chaitra S. R.
}

\author{
Department of Pharmacology, \\ Yenepoya Medical College, \\ Yenepoya (Deemed to be \\ University), Mangalore, \\ Karnataka, India
}

Received: 27 October 2018 Accepted: 29 November 2018

\section{*Correspondence to: \\ Dr. Roopa P. Nayak, Email: roopapnayak@ yenepoya.edu.in}

Copyright: (C) the author(s), publisher and licensee Medip Academy. This is an openaccess article distributed under the terms of the Creative Commons Attribution NonCommercial License, which permits unrestricted noncommercial use, distribution, and reproduction in any medium, provided the original work is properly cited.

\begin{abstract}
Background: There is a growing demand for alternative medicines derived from indigenous plants having natural antioxidants and neuroprotective actions for the treatment of many behavioural disorders such as anxiety and depression. This study was designed to screen antidepressant activity of aqueous extract of Piper betle L. leaf (betel leaf) in Swiss albino mice.

Methods: Swiss albino mice of both sexes weighing 25-30grams were used in the present study. Piper betle leaves aqueous extract (PBAE) was administered to the animals at a dose of $100,200 \mathrm{mg} / \mathrm{kg}$ body weight orally for 14 days. On the $14^{\text {th }}$ day, after 1 hour of PBAE administration, experiments on force swim test (FST) and tail suspension (TST) were carried out for studying the level of depression. In FST and TST, time of immobility was noted for a period of 5 minutes.

Results: Data was analyzed by one-way ANOVA followed by Tukey Kramer's multiple comparison test at $\mathrm{P}=0.05$. The results were represented as Mean $\pm \mathrm{SE}$. $\mathrm{PBAE}$ at a dose of $100 \mathrm{mg} / \mathrm{kg}$ has shown significant antidepressant activity, as evidenced by decrease in the immobility time in both the screening tests of depression.

Conclusions: Present results demonstrated that PBAE possess potent antidepressant property. The exact mechanism(s) related to the active compound(s) in Piper betle leaf extract have to be elucidated in future studies.
\end{abstract}

Keywords: Aqueous extract, Antidepressant, Leaf, Piper betle, Swiss albino mice

\section{INTRODUCTION}

Depression is one of the most prevalent diverse mood disorders and is one of the five leading causes of disability and disease burden worldwide. The proportion of the global population that suffers from depression is estimated to be $4.4 \%$ which is 350 million people worldwide. ${ }^{1}$ The prevalence rate of this disorder is more common among females $(5.1 \%)$ than males $(3.6 \%) .{ }^{1}$ Symptoms of this mood disorder are biological elements like impedance of thought, sleep disorder, loss of appetite and libido. The symptoms of emotional factors are sadness, apathy, pessimism, low self- respect, feeling of guilt, loss of enthusiasm and indecisiveness.

The most successful group of antidepressants at present are selective serotonin reuptake inhibitors (SSRIs), selective nor-adrenaline reuptake inhibitors (SNRIs), tricyclic antidepressants (TCAs) and selective reversible inhibitors of monoamine oxidase-A (MAO-A). These drugs target and affect the levels of monoamine transmitters in the central nervous system (CNS). ${ }^{2}$ Though SSRIs and SNRIs are the most potent antidepressants till date, a major drawback of these agents is the 2-4 weeks lag time to show antidepressant effect. During this lag time the risk for 
suicide and the patient's suffering persists which is a clinical scourge. , $^{2,3}$

The effective management of this CNS disorder remains a major clinical problem. Though several drugs are available, all are associated with some limitations and there is an urgent need for alternative medications for these disorders. Probably a bio-active constituent of plant origin may have a role in this aspect.

One of the medicinal plants to be considered in this regard would be Piper betle L. (betel leaf) belongs to Piperaceae family because of many biologically active compounds it possesses. Phytochemical studies confirmed the presence of chavibetol, chavicol, hydroxychavicol, diosgenin, eugenol, allylpyrocatechol, methyl eugenol, triterpenes and $\beta$-sitosterol in Piper betle, which are responsible for its various pharmacological properties like antiplatelet, antibacterial, antioxidant, anti-inflammatory, immunomodulatory, hepatoprotective, gastro-protective and antidiabetic activity. ${ }^{4,5}$ The neuroprotective action of ethanolic extract of Piper betle leaves on mice are also reported. ${ }^{6,7}$ In this study, aqueous extract of Piper betle leaf was screened for its antidepressant's activity in Swiss albino mice.

\section{METHODS}

\section{Experimental animals}

Swiss albino mice of both sexes, weighing 25-30g were used in this study. They were kept under standard housing conditions with free access to standard pellet diet and water ad libitum. The study was conducted in the Ethnopharmacology lab, Department of Pharmacology, Yenepoya Medical College, Mangalore after obtaining Institutional animal ethics committee (IAEC) clearance (6/9.6.2016).

\section{Inclusion criteria}

- Healthy Swiss Albino mice of either sexes

- Weight: 25-30g

- $\quad$ Age: 3-4 months

- Healthy with normal behaviour and activity.

\section{Exclusion criteria}

- Unhealthy animal

- Obese animal

- Pregnant animal

- Animals previously used in other experiments

\section{Chemicals}

Distilled water was used to prepare plant extract. Imipramine hydrochloride (obtained from Yenepoya Hospital Pharmacy, Mangalore) was used as a standard drug for antidepressant activity.

\section{Plant material}

Aqueous extract of Piper betle (PBAE)

The fresh leaves of young Piper betle leaves were collected in the month of March from the market at Kasaragod, Kerala. Authentication was done by a botanist, Mangalore University. The leaves were shade dried, and then ground into coarse powder using mechanical grinder. Dried powder was taken in soxhlet extractor and extracted using distilled water $(1000 \mathrm{ml})$ as solvent in Soxhlet apparatus at $70^{\circ} \mathrm{C}-80^{\circ} \mathrm{C}$ for 23 hours. The obtained extract was concentrated using Rota- vapour. The extract in the paste form was collected and stored in the refrigerator till further use. ${ }^{8,9}$

\section{Acute oral toxicity study of PBAE}

Acute toxicity study of aqueous extract of Piper betle leaves was done according to Organization of Economic Co-operation and Development (OECD) guidelines 425 limit test at the dose of $2000 \mathrm{mg} / \mathrm{kg} .{ }^{10}$ Five female Swiss albino mice was administered with PBAE in a single dose of $2000 \mathrm{mg} / \mathrm{kg}$ per orally to identify the safe dose range in animals. Animals were observed individually for $48 \mathrm{hrs}$ from the time of drug administration. Observations included general behaviour and mortality. The highest dose of PBAE $(2000 \mathrm{mg} / \mathrm{kg})$ tried in mice did not show any behavioural changes or mortality which implies that $\mathrm{LD}_{50}$ of PBAE is above $2000 \mathrm{mg} / \mathrm{kg}$. In the present study the dose fixed at $100 \mathrm{mg} / \mathrm{kg}$ and $200 \mathrm{mg} / \mathrm{kg}$ were used. ${ }^{11}$

\section{Experimental design}

A total of 48 mice $(n=48)$ were used. Animals were divided into 4 different groups, for each experimental model (total - eight groups). Each group consisted of 6 animals.

- Group I: Distilled water $(10 \mathrm{ml} / \mathrm{kg})$ orally.

- Group II: Imipramine $10 \mathrm{mg} / \mathrm{kg}$ orally. ${ }^{12}$

- Group IV: PBAE- $100 \mathrm{mg} / \mathrm{kg}$ orally.

- Group VI: PBAE- $200 \mathrm{mg} / \mathrm{kg}$ orally.

All the groups were treated with vehicle, test PBAE $(100 \mathrm{mg} / \mathrm{kg}$ and $200 \mathrm{mg} / \mathrm{kg}$ ) and standard drug for period of 14 days. On the $14^{\text {th }}$ day, after an hour of administration of drugs, animals were screened for antidepressant activity. The antidepressant activity of the test drug was evaluated using the following experimental models of depression (i) Forced Swim Test (FST) and (ii) Tail Suspension Test (TST). Animals were weighed, and appropriate dose of the drug was administered per orally (p.o.) to the different groups.

\section{Forced Swim Test (FST)}

This behavioural despair paradigm was described by Porsolt et al, and is the most widely used pharmacological model for assessing antidepressant activity. ${ }^{13}$ The development of immobility when the rodents are placed in 
an inescapable cylinder of water reflects the cessation of persistent escape-directed behaviour. The apparatus consists of a clear rectangular glass jar $(15 \mathrm{~cm} \times 11.5 \mathrm{~cm} \times$ $15 \mathrm{~cm})$, water up to $10 \mathrm{~cm}$. Depth was sufficient to keep the mice from supporting themselves by placing their paws or tails on the base of the cylinder. Water was changed between each swim session to prevent possible effects of an alarm substance released by animals during the swim session. During the test session, the immobility time was recorded for 5minutes, when the mice make no further attempts to escape, and makes only movements to keep its head above the water. ${ }^{14}$

\section{Tail suspension test (TST)}

The tail-suspension test is the second method for assessing the depressive state and this method was described by Steru et al. ${ }^{13}$ The mice were suspended on a pole $50 \mathrm{~cm}$ above, by the tail with sticky tape. After the initial period of vigorous motor activity, the mice become still, and the immobility time was measured with a stopwatch, for a total duration of 5 minutes. Mice were considered immobile when they hang passively and completely motionless. ${ }^{14}$

\section{Statistical analysis}

Results were expressed as mean \pm SE. One-way analysis of variance (ANOVA) was carried out and the statistical comparisons among the groups were performed with Tukey Kramer test with level of significance $P=0.05$. For data analysis, SPSS v23.0 was used.

\section{RESULTS}

\section{Forced swim test}

Both doses of Piper betle leaf aqueous extracts showed significantly lower duration of immobility than the Normal (Table 1).

Table 1: Comparison of test groups in forced swim test.

\begin{tabular}{|lll|}
\hline Group & Drugs & $\begin{array}{l}\text { Duration of } \\
\text { immobility in seconds }\end{array}$ \\
\hline I & Normal (DW) & $207.16 \pm 11.18$ \\
\hline II & Imipramine & $50.08^{\mathrm{a}} \pm 1.19$ \\
\hline III & PBAE $100 \mathrm{mg} / \mathrm{kg}$ & $64.67^{\mathrm{a}} \pm 8.37$ \\
\hline IV & PBAE $200 \mathrm{mg} / \mathrm{kg}$ & $104.00 \pm 11.15$ \\
\hline
\end{tabular}

Values with common superscripted alphabets indicate homogeneity among the respective groups as per Tukey's test $(\mathrm{P}=0.05)$ following one-way analysis of variance. Values are expressed as mean \pm SE $(n=6)$. DW: Distilled water; PBAE: Piper betle aqueous extract; SE: Standard Error of mean.

Lowest duration of immobility was observed in the group that received standard drug imipramine, but it is not significantly different from the group that received Piper betle leaf aqueous extract $100 \mathrm{mg} / \mathrm{kg}$. The decrease in duration of immobility in the groups of Piper betle leaf aqueous extracts clearly confirms the antidepressant property of this medicinal plant. Further effect of dose of $100 \mathrm{mg} / \mathrm{kg}$ is comparable with that of standard drug according to the results of FST.

\section{Tail suspension test}

Least duration of immobility in TST was seen in group that received Piper betle leaf aqueous extract $100 \mathrm{mg} / \mathrm{kg}$, which is significantly lower to other three groups (Table 2). The effect of dose $200 \mathrm{mg} / \mathrm{kg}$ is not that distinctive as its value grouped with the standard drug in one hand again with normal on the other hand. The duration of immobility in standard drug is however significantly lower than the normal. The result of TST clearly indicates antidepressant property of Piper betle, especially with aqueous extract $100 \mathrm{mg} / \mathrm{kg}$.

Table 2: Comparison of test groups in tail suspension test.

\begin{tabular}{lll|}
\hline Group & Drugs & $\begin{array}{l}\text { Duration of } \\
\text { immobility in seconds }\end{array}$ \\
\hline I & Normal (DW) & $163.11^{\mathrm{a}} \pm 8.32$ \\
\hline II & Imipramine & $125.03^{\mathrm{b}} \pm 4.27$ \\
\hline III & PBAE $100 \mathrm{mg} / \mathrm{kg}$ & $53.50 \pm 10.95$ \\
\hline IV & PBAE $200 \mathrm{mg} / \mathrm{kg}$ & $136.83^{\mathrm{ab}} \pm 12.52$ \\
\hline $\begin{array}{l}\text { Values } \\
\text { homogeneity among the respective groups as per Tukey's test }\end{array}$ \\
$\begin{array}{l}\text { (P=0.05) following one-way analysis of variance. Values are } \\
\text { expressed as mean } \pm \text { SE }(\mathrm{n}=6) \text {. DW: Distilled water; PBAE: Piper } \\
\text { betle aqueous extract; SE: Standard Error of mean. }\end{array}$
\end{tabular}

\section{DISCUSSION}

Undesirable side effects of current antidepressant medications have forced to think about alternative treatment strategies such as ayurvedic or herbal preparations having lesser side effects and can be made available in cost-effective manner. One of the promising herbal alternatives would be Piper betle leaf which is authenticated by the traditional uses as well as by the studies on pharmacological activity. ${ }^{15}$

To screen the antidepressant activity the present study has used two validated behavioural models, TST and FST. Animals when subjected to these models would develop an inescapable stress that induces a characteristic behaviour of immobility. The immobility reflects a state of despair in animals, that can be related to condition similar to human depression and this can be reduced by several agents which are therapeutically effective in human depression. ${ }^{16}$ In this study, aqueous extract of Piper betle leaves showed significant antidepressant activity in the animal models of depression as evidenced by decrease in immobility time in FST and TST. Aqueous extract of Piper betle $100 \mathrm{mg} / \mathrm{kg}$ body weight has showed significant antidepressant activity than aqueous extract of Piper betle $200 \mathrm{mg} / \mathrm{kg}$ body weight. Similar observations were reported in previous study on Piper betle ethanolic extracts $(100 \mathrm{mg} / \mathrm{kg}$ and $200 \mathrm{mg} / \mathrm{kg}){ }^{6}$ 
Superiority of aqueous extract of Piper betle at $100 \mathrm{mg} / \mathrm{kg}$ over $200 \mathrm{mg} / \mathrm{kg}$ may be due to therapeutic window phenomenon which could be used as a guide to formulate the dose in future investigations.

The mechanism of action of the Piper betle could be due to the presence of phenolic compounds such as chavibetol, chavicol and eugenol. ${ }^{4}$ Chavicol is a phenylpropene, which is found to increase the levels of monoamines like norepinephrine, serotonin and dopamine levels thus causing antidepressant like activity as mentioned in previous studies. ${ }^{17}$ In this study antidepressant-like activity would be attributed to its monoamine modulating effects, however, further studies are required to confirm the phytoconstituent responsible for the observed antidepressant effect of PBAE at a dose of $100 \mathrm{mg} / \mathrm{kg}$ and to explain antidepressant mechanism.

\section{CONCLUSION}

From this study it can be concluded that Piper betle aqueous extract has a significant antidepressant activity. However further study has to be done to explore the role of active component present in Piper betle aqueous extract (PBAE). Also, PBAE may have potential therapeutic value for the management of depressive disorders.

\section{ACKNOWLEDGEMENTS}

Authors would like to thank all the teaching and nonteaching staffs of Department of Pharmacology, Yenepoya Medical College, Mangalore, Karnataka, for their valuable support in carrying out this research work.

\section{Funding: No funding sources}

Conflict of interest: None declared

Ethical approval: The study was approved by the Institutional Ethics Committee

\section{REFERENCES}

1. World Health Organisation. Depression and Other Common Mental Disorders Global Health Estimates. Geneva: World Health Organisation; 2017. Available at:

http://www.searo.who.int/india/depression_in_india.p df. Accessed 14 June 2018.

2. Rabiei Z, Jahanbazi S, Alibabaei Z, Rafieiani MK. Antidepressant effects of oleuropein in male mice by forced swim test and tail suspension test. World Fam Med Middle East J Fam Med. 2018 Apr;16(4):132-44.

3. Ponciano LJ, Rosas-Sánchez GU, Domínguez ER, Rodríguez-Landa JF. Advances in the Preclinical Study of Some Flavonoids as Potential Antidepressant Agents. Scientifica. 2008 Feb:1-14.

4. Shah SK, Garg G, Jhade D, Patel N. Piper betle: phytochemical, pharmacological and nutritional value in health management. Int J Pharmaceut Sci Rev Res. 2016;38:181-9.

5. Dwivedi V, Tripathi S. Review study on potential activity of Piper betle. J Pharmacogn Phytochem. 2014;3(4):93-8.

6. Swati B, Madhusudhanan N. Antidepressant activity of ethanolic extract of Piper betle leaves in mice. Curr Res Neurosci. 2012;2(1):11-6.

7. Gulhane H, Misra AK, Reddy P, Pandey D, Gulhane R, Varma SK. Effects of Piper betle leaves (paan) extract as anti-depressant and anti-anxiety in experimental animals. Mintage J Pharmaceut Med Sci. 2015 Apr-Jun;4(2):12-5.

8. Evans WC. Trease \& Evan's Pharmacognosy. 16th ed. Edinburg: Saunders Elseveir;2009:121-5.

9. Sherikar AS, Mahanthesh MC. Evaluation of aqueous and methanolic extract of leaves of Epipremnum aureum for radical scavenging activity by DPPH Method, total phenolic content, reducing capacity assay and FRAP assay. J Pharmacogn Phytochem. 2015;4(4):36-40.

10. Organisation for Economic Co-operation and Development.Guidance document on acute oral toxicity testing. Paris: Organisation for Economic Cooperation and development;2001. Available at: http://www.oecd.org/officialdocuments/publicdisplay documentpdf/?cote=env/jm/mono(2001)4\&doclangu age=en. Accessed 21 March 2018.

11. Ghosh MN. Fundamentals of experimental pharmacology. 6th ed. Kolkata: Hilton \& Company;2015:165.

12. Shastry R, Sharma A, Sayeli V, Dinkar US. Screening of Antidepressant Activity of Punica granatum in Mice. Pharmacogn J. 2017;9(1):27-9.

13. Vogel HG(Ed.). Drug Discovery and Evaluation:Pharmacological Assays. 3rd ed. Berlin: Spinger-verlag; 2008.p788-93.

14. Dhingra. D, Sharma. A. Evaluation of antidepressant like activity of Glycyrrhycin in Mice. Indian J Pharmacology, 2005;6:390-4.

15. Zarghami M, Chabra A, Khalilian A, Asghar Hoseini A. Antidepressant Effect of Asperugo procumbens L. in Comparison with Fluoxetine: a Randomized Double Blind Clinical Trial. Res J Pharmacog. 2018 Jun $1 ; 5(3): 15-20$.

16. Xia F, Li C, Li M, Liao Y, Liu X, Si J, et al. Antidepressant activity of an aqueous extract from okra seeds. RSC Adv. 2018;8(57):32814-22.

17. Dhingra D, Goyal PK. Evidences for the involvement of monoaminergic and GABAergic systems in antidepressant-like activity of Tinospora cordifolia in mice. Indian J Pharmaceut Sci. 2008 Nov;70(6):7617.

Cite this article as: Krishna U, Nayak RP, Chaitra SR. Preclinical evaluation of antidepressant activity of aqueous extract of Piper betle leaves in Swiss albino mice. Int J Basic Clin Pharmacol 2019;8:1436. 